Serat Rupa Journal of Design, July 2019, Vol.3, No.2: 77-92

E-ISSN: 2477-586X, ISSN: 2338-3348 | https://doi.org/10.28932/srjd.v3i2.1728 | Received: 24-06-2019, Accepted: 25-07-2019

Yovita Sabatini Daeli, Dewi Isma Aryani, Indra Janty

Perancangan Busana Ready To Wear Deluxe dengan Inspirasi The culture of Animal Spirit dari Suku Indian

\title{
PERANCANGAN BUSANA READY TO WEAR DELUXE DENGAN INSPIRASI THE CULTURE OF ANIMAL SPIRIT DARI SUKU INDIAN
}

\author{
Yovita Sabatini Daeli, Dewi Isma Aryani, Indra Janty \\ (Email: yovitasabatini14@gmail.com) \\ Program Studi D-III Seni Rupa dan Desain \\ Fakultas Seni Rupa dan Desain \\ Universitas Kristen Maranatha \\ Jl. Prof.drg. Suria Sumantri, MPH no. 65, Bandung, Indonesia
}

\begin{abstract}
ABSTRAK
Suku Indian merupakan penduduk asli Amerika Utara yang terkenal dengan tradisi, gaya hidup, bentuk seni, dan kepercayaan sebagai suatu tradisi kebudayaan. Salah satu tradisi kepercayaan Suku Indian terhadap roh hewan yang berkaitan dengan agama suku Indian yaitu animisme. Dalam kepercayaan roh hewan ada beberapa hewan yang dianggap penting sebagai tahapan aspek kehidupan suku Indian yaitu: elang, serigala, beruang, dan bison dilambangkan sebagai dasar struktur kehidupan bagi suku Indian. Penggabungan simbol kepercayaan tersebut berdasarkan arah mata angin, musim, elemen, dan warna setiap lambang dari roh hewan yang menjadi inspirasi perancangan koleksi busana ready-to-wear deluxe berjudul OTODEM. Melalui koleksi OTODEM ditampilkan nuansa etnik namun tetap modern dari segi bentuk atau potongan busana. Konsep yang diterapkan pada desain mengadaptasi bentuk rupa dari roh hewan yaitu: elang, serigala, beruang, dan bison di setiap busana serta dari simbol arah mata angin, musim, elemen, dan warna. Simbol atau lambang diaplikasikan pada busana melalui teknik sablon polyflex dan flocking pada bagian motif lambang atau simbol, teknik Macrame dan Stitching digunakan untuk menunjukkan ciri khas dari pakaian Suku Indian. Tujuannya adalah memperkuat tampilan dan berkesan serupa dengan simbol atau lambang dari Suku Indian. Koleksi ready-to-wear deluxe ditujukan bagi pria dan wanita dengan rentang umur 25-35 tahun, memiliki profesi sebagai entertainer, desainer dan figur publik dengan karakter yang berani, menyukai tantangan dan suka mencoba hal baru, menyukai hal terkait budaya/etnik, serta berdomisili di kota-kota besar Indonesia.
\end{abstract}

Kata kunci: etnik; hewan; kepercayaan; simbol; Suku Indian

\begin{abstract}
Indian tribes are the people of North America who are famous for their tradition, lifestyle, art and belief as culture tradition. One of the belief tradition is their belief to the spirit of animal which has connection with Indian belief,animism. In animal animism there are several animals which is considered.sacred in the lifecycle of Indians. They are : eagles, bear, and bisons. They are the symbols of life structure to Indian tribes. The combination of the symbols of lifecycle is based on the ways of the winds, seasons, elements, and colors of each of the symbols has become the inspiration of fashion design ready to wear collection deluxe titled OTODEM Throughout OTODEM collection the ethnic but still modern nuances are shown from the shapes and cutting of the clothes. The concept applied on the design adapts the symbols If animal spirit : eagles, wolves, bear and bison and also from the symbols of ways of the wind, seasons, elements, and colors in every piece of clothing. The symbols are applied on the piece of clothings throughout polyflex screen printing and flocking and the sign motifs, the macrame and stitching technique are used to show the uniqueness of the Indian tribe clothes. The goal is to strengthen the performance and similarities with symbols of Indian tribes. This ready to wear collection is targeted for men and women around 25-35 years old with different backgrounds such as entertainers, designers and public figures with strong and bold characteristics, love challenges and are open to new challenges, curious about ethnics and cultures, and stay in major cities in Indonesia.
\end{abstract}

Keywords: animal, belief, ethnic, India Tribes, symbol 
Serat Rupa Journal of Design, July 2019, Vol.3, No.2: 77-92

E-ISSN: 2477-586X, ISSN: 2338-3348 | https://doi.org/10.28932/srjd.v3i2.1728| Received: 24-06-2019, Accepted: 25-07-2019 Yovita Sabatini Daeli, Dewi Isma Aryani, Indra Janty

Perancangan Busana Ready To Wear Deluxe dengan Inspirasi The culture of Animal Spirit dari Suku Indian

\section{PENDAHULUAN}

Penduduk Indian terbagi atas beberapa wilayah yang hidup dalam kelompok suku secara terpisah di benua Amerika. Meskipun demikian banyak dari mereka memiliki kepercayaan dan budaya yang sama. Suku Indian merupakan penduduk asli Amerika Utara yang terkenal dengan tradisi, gaya hidup, bentuk seni, dan kepercayaan sebagai suatu tradisi kebudayaan mereka. Salah satu tradisi kepercayaan mereka terhadap roh hewan berkaitan dengan agama Suku Indian yaitu animisme. Roh hewan dalam Suku Indian sangat dihormati dan dianggap suci, sehingga dalam budaya dan kehidupan sehari-hari Suku Indian selalu dikaitkan oleh roh hewan, seperti bentuk seni, upacara adat, dan gaya hidup mereka yang berkaitan dengan roh hewan tersebut (Linda, 2012). Roh hewan dianggap sebagai makhluk tertinggi dengan kekuatan supernatural yang menjadi pelindung, pembimbing, dan sebagai pemandu jalan untuk menjalani kehidupan di dunia. Sebagai wujud roh hewan Suku Indian digambarkan ke dalam bentuk seni yaitu seni totem dan simbol-simbol dalam tradisi kebudayaan mereka. Dalam kepercayaan roh hewan ada beberapa hewan yang dianggap penting sebagai tahapan aspek kehidupan Suku Indian yaitu: elang, serigala, beruang dan bison dilambangkan sebagai dasar struktur kehidupan bagi Suku Indian dengan menggabungkan beberapa unsur seperti: arah mata angin, musim, elemen, dan warna dari roh hewan yang dianggap penting (Linda, 2012).

\section{METODE PENELITIAN}

Perancangan ini dibuat berdasarkan penelitian yang dilakukan dengan metode kualitatif berupa observasi lapangan dan referensi mode Indonesia yakni buku Trend Forecasting 2018/2019 Singularity bertema Svarga dan subtema Festive Relics.

Adapun teori-teori yang digunakan dalam penelitian sebagai referensi perancangan antara lain:

1. Teori budaya Suku Indian, dalam hal ini terkait dengan kepercayaan terhadap roh hewan.

2. Teori warna, terkait dengan penggunaan warna pada busana Suku Indian dan warna inspirasi dari lingkaran kehidupan yang diaplikasikan dalam perancangan busana.

\section{Makna Warna Menurut Kepercayaan Suku Indian}

Busana ready to wear deluxe OTODEM yang terinspirasi dari The Culture Of Animal Spirit memakai warna yang merah-oranye, kuning mustard, hitam, dan putih broken white. Dari keempat elemen warna tersebut diambil berdasarkan budaya kepercayaan Suku Indian 
Serat Rupa Journal of Design, July 2019, Vol.3, No.2: 77-92

E-ISSN: 2477-586X, ISSN: 2338-3348 | https://doi.org/10.28932/srjd.v3i2.1728| Received: 24-06-2019, Accepted: 25-07-2019 Yovita Sabatini Daeli, Dewi Isma Aryani, Indra Janty

Perancangan Busana Ready To Wear Deluxe dengan Inspirasi The culture of Animal Spirit dari Suku Indian

yang memiliki makna dan arti tertentu yaitu:

Tabel 1. Makna warna menurut kepercayaan Suku Indian

\begin{tabular}{|c|c|c|}
\hline No. & Warna & Makna menurut Kepercayaan Suku Indian \\
\hline 1. & Mera & $\begin{array}{l}\text { Kekerasan, perang, darah, luka, kekuatan, energi, kekuatan } \\
\text { dan kesuksesan (cat perang), tetapi juga melambangkan } \\
\text { kebahagiaan dan keindahan (cat wajah). }\end{array}$ \\
\hline 2. & Kuning $\mathrm{N}$ & $\begin{array}{l}\text { Kematian, heroik, telah menjalani kehidupan yang baik dan } \\
\text { bersedia bertarung sampai mati, kecerdasan. }\end{array}$ \\
\hline 3. & Hitz & $\begin{array}{l}\text { Hidup dan dikenakan pada wajah untuk mempersiapkan } \\
\text { perang, sangat agresif, kekuatan yang juga } \\
\text { mengindikasikan bahwa pemakainya adalah pejuang yang } \\
\text { kuat dalam pertempuran, kemenangan dan diterapkan } \\
\text { sebelum kembali ke rumah/ camp. }\end{array}$ \\
\hline 4. & Putih Broken White & $\begin{array}{l}\text { Duka, kedamaian dan kebahagiaan, musim dingin atau } \\
\text { salju. Putih Broken White adalah warna kedamaian saat } \\
\text { digunakan (cat wajah). }\end{array}$ \\
\hline
\end{tabular}

(Sumber: Linda, 2012)

Berdasarkan ringkasan landasan teori tentang kebudayaan dan warna yang ada pada Suku Indian di atas, maka dapat ditampilkan melalui image board sebagai berikut: 
Serat Rupa Journal of Design, July 2019, Vol.3, No.2: 77-92

E-ISSN: 2477-586X, ISSN: 2338-3348 | https://doi.org/10.28932/srjd.v3i2.1728| Received: 24-06-2019, Accepted: 25-07-2019 Yovita Sabatini Daeli, Dewi Isma Aryani, Indra Janty

Perancangan Busana Ready To Wear Deluxe dengan Inspirasi The culture of Animal Spirit dari Suku Indian

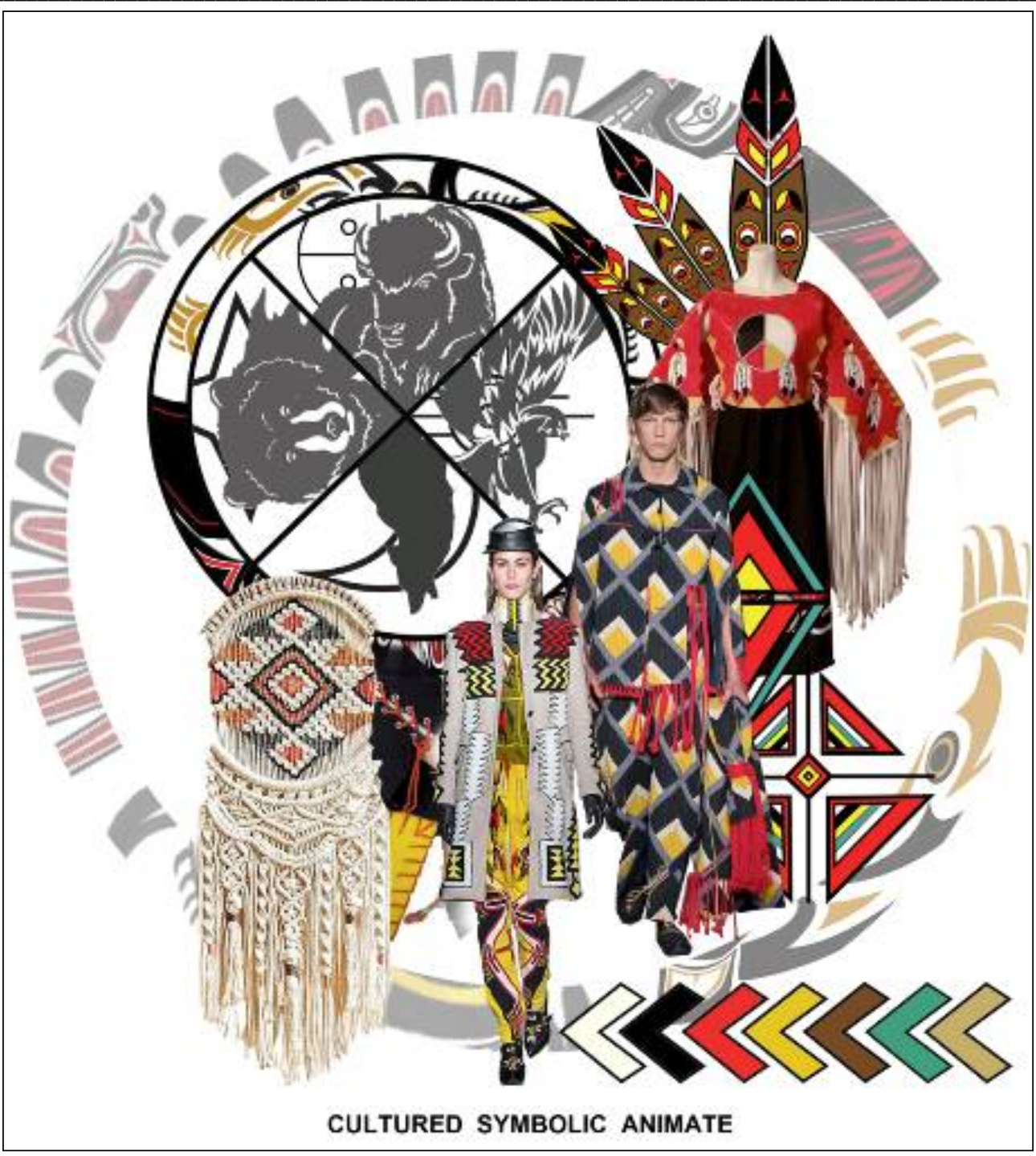

Gambar 1. Image Board

(Sumber: Data. Pribadi, 2019)

\section{Teknik Reka Bahan}

Teknik manipulating fabric atau reka bahan merupakan teknik menyusun, mengatur, atau mengarang bahan yang dalam penelitian ini digunakan beberapa teknik manipulasi, yaitu:

1. Sablon

a. Sablon Polyflex Printable

Polyflex Printable merupakan media untuk kanvas mencetak gambar atau desain secara khusus memerlukan mesin digital printing untuk proses cetaknya. Aplikasi bahan polyflex printable dilengkapi mesin cutting sticker sebagai alat potong suatu gambar atau bentuk yang sudah diatur terlebih dahulu. 
Serat Rupa Journal of Design, July 2019, Vol.3, No.2: 77-92

E-ISSN: 2477-586X, ISSN: 2338-3348 | https://doi.org/10.28932/srjd.v3i2.1728 | Received: 24-06-2019, Accepted: 25-07-2019 Yovita Sabatini Daeli, Dewi Isma Aryani, Indra Janty

Perancangan Busana Ready To Wear Deluxe dengan Inspirasi The culture of Animal Spirit dari Suku Indian

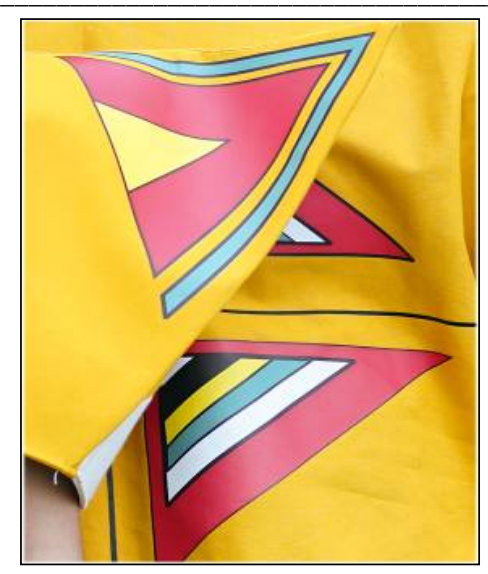

Gambar 2. Sablon Polyflex Printable dalam busana OTODEM

(Sumber: Data Pribadi, 2019)

\section{b. Sablon Flocking}

Proses flocking merupakan proses penambahan serat filamen seperti beludru pada bahan atau kain yang sebelumnya telah dilapisi oleh lem. Biasanya flocking dilakukan dengan menggunakan teknik sablon frame, lem SP TOP INK dipanaskan selama 10 detik dengan suhu $160^{\circ}$ Celcius.

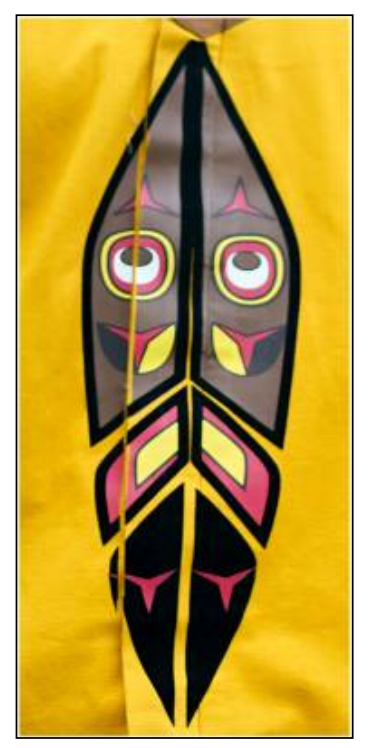

Gambar 3. Sablon Flocking dalam busana OTODEM (Sumber: Data Pribadi, 2019)

\section{Macrame}

Bentuk seni kerajinan simpul-menyimpul dengan menggarap simpul rantaian benang awal dan akhir menjadi suatu hasil tenunan tersebut sehingga terbentuk aneka rumbai dan jumbai. Macrame adalah salah satu produk kerajinan yang berasal dari keahlian merangkai tali. Macrame berarti kerajinan simpul tali dengan keahlian menyimpul tali, baik dua buah tali, empat buah tali, dan sebagainya sehingga menghasilkan sebuah karya kerajinan yang 
Serat Rupa Journal of Design, July 2019, Vol.3, No.2: 77-92

E-ISSN: 2477-586X, ISSN: 2338-3348 | https://doi.org/10.28932/srjd.v3i2.1728| Received: 24-06-2019, Accepted: 25-07-2019 Yovita Sabatini Daeli, Dewi Isma Aryani, Indra Janty

Perancangan Busana Ready To Wear Deluxe dengan Inspirasi The culture of Animal Spirit dari Suku Indian

selain berfungsi sebagai benda pakai juga mempunyai seni yang menarik (Hariyanto, 2011).

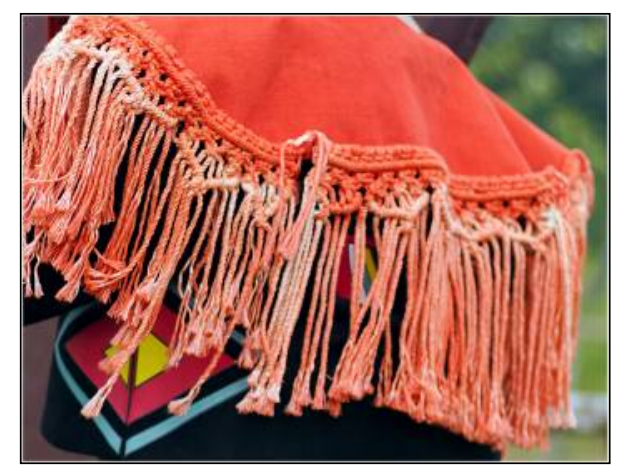

Gambar 4. Macrame dalam busana OTODEM (Sumber: Data Pribadi, 2019)

\section{Stitching}

a. Cross Stitch adalah salah satu bentuk penyulaman pada kain tertentu dengan menyulam benang-benang membentuk tanda silang $(X)$. Untuk memulai suatu cross stitch diperlukan sebuah pattern sebagai patokan dalam menyulam.

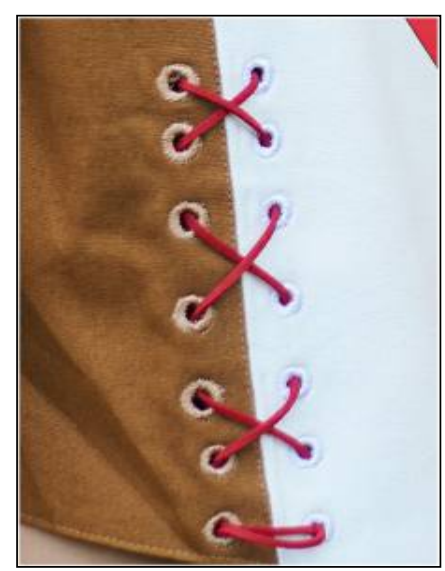

Gambar 5. Cross Stitch dalam busana OTODEM

(Sumber: Data Pribadi, 2019)

b. Festoon Stitch atau tusuk feston berfungsi untuk merekatkan dua permukaan kain supaya tidak bergerak, penerapan teknik tusuk ini biasanya dipakai pada bagian ujung atau tepi kain. Teknik tusuk ini biasanya digunakan oleh pengrajin dalam mebuat kerajinan dari kain flanel. 


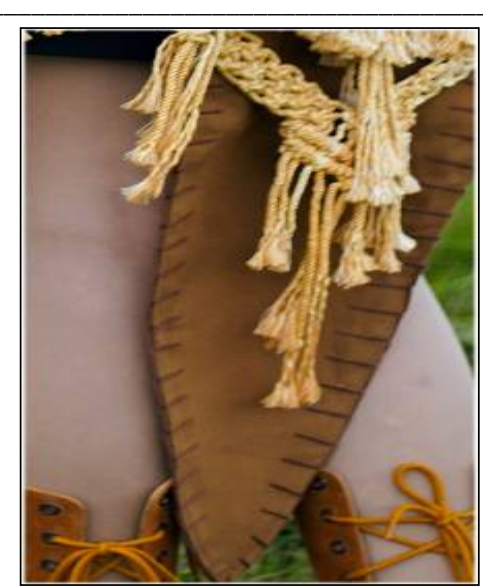

Gambar 6. Festoon Stitch dalam busana OTODEM (Sumber: Data Pribadi, 2019)

\section{PEMBAHASAN}

Konsep perancangan karya ini terinspirasi dari The Culture of Animal Spirit yang merupakan lambang dan simbol dari keempat hewan penting dalam tahapan aspek kehidupan Suku Indian yang memiliki makna dan tujuan sebagai arah proses tahapan kehidupan dimulai dari kelahiran, masa remaja, masa dewasa, hingga kematian. Adapun warna yang digunakan dalam perancangan ini terinspirasi dari warna yang dipakai yakni warna merah oranye, kuning mustard, hitam, dan putih sebagai warna utama dari lingkaran kehidupan. Sedangkan warna tambahan yakni cokelat camel, biru pirus, dan cream digunakan sebagai warna simbol dan lambang arah mata angin Suku Indian.

Kajian telaah tentang referensi tren fesyen diambil dari buku Indonesia Trend Forecasting 2018/2019 Singularity dengan tema Svarga, yang berasal dari bahasa Sansekerta berarti surge. Tema tren Svarga mewakili latar belakang kultural dari simbol dengan dampak yang dihasilkan manusia, menciptakan surga di atas bumi. Konsep desain dengan tema ini memperlihatkan tabrak corak yang tetap selaras dengan keseimbangan antara satu dengan yang lain, menunjukkan pesona dari tradisi yang tak ternilai harga dan kearifan lokal kriya budaya tradisional (Indonesia Trend Forecasting Singularity, 2019). 
Serat Rupa Journal of Design, July 2019, Vol.3, No.2: 77-92

E-ISSN: 2477-586X, ISSN: 2338-3348 | https://doi.org/10.28932/srjd.v3i2.1728| Received: 24-06-2019, Accepted: 25-07-2019 Yovita Sabatini Daeli, Dewi Isma Aryani, Indra Janty

Perancangan Busana Ready To Wear Deluxe dengan Inspirasi The culture of Animal Spirit dari Suku Indian

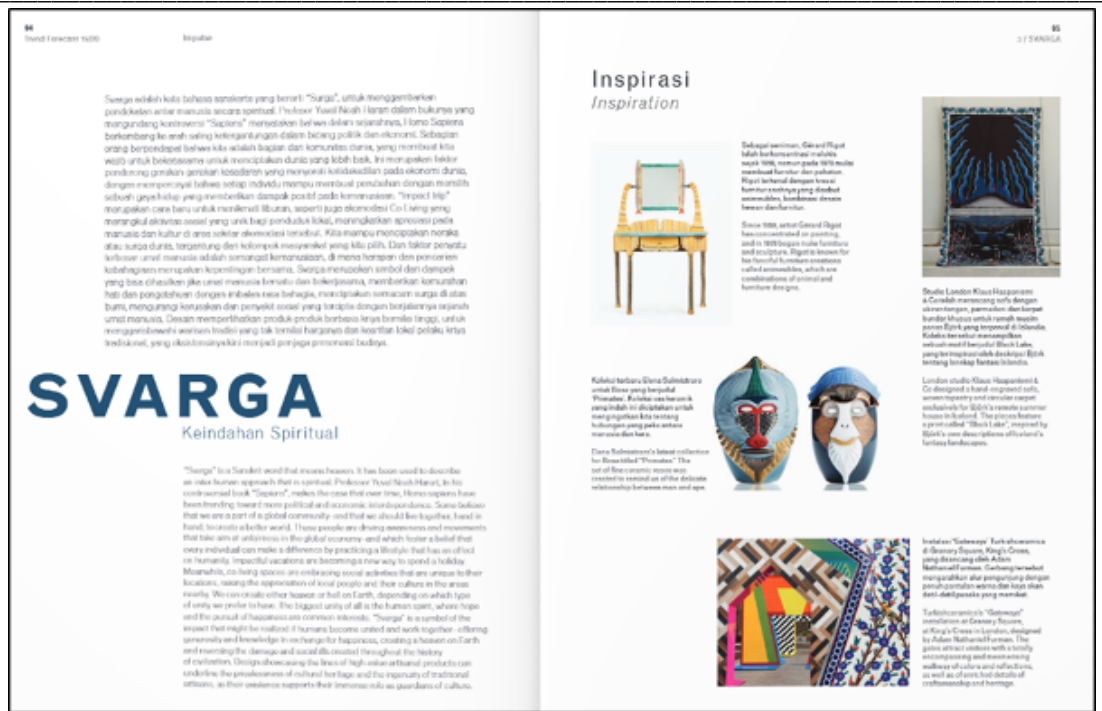

Gambar 7. Tema Svarga

(Sumber: Indonesia Trend Forecasting Singularity 2019/2020)

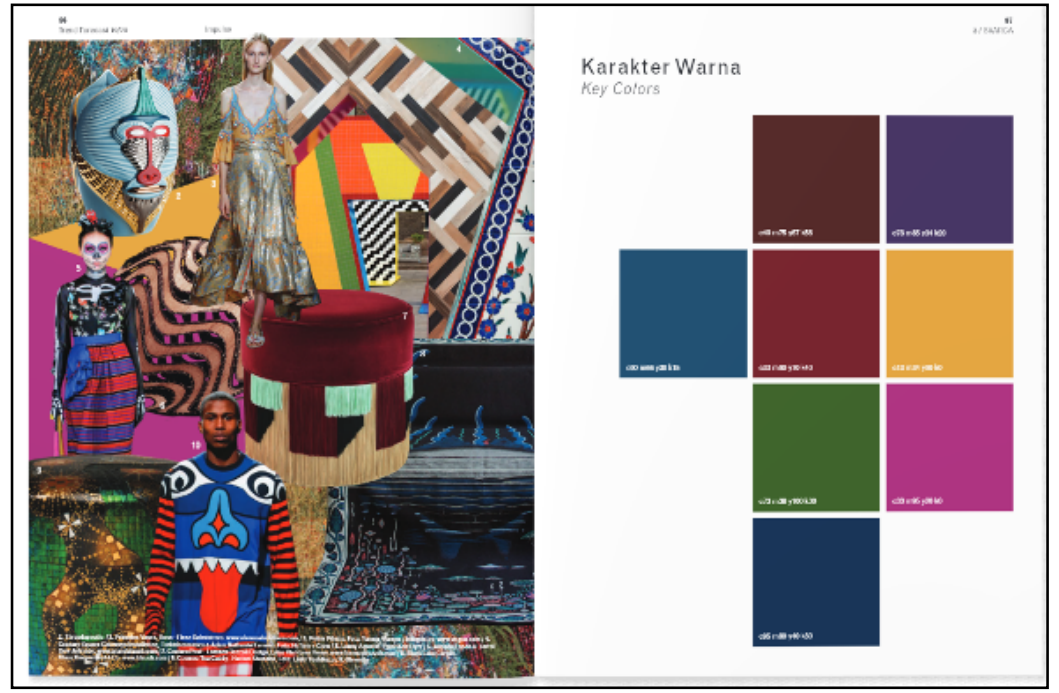

Gambar 8. Color Chart Tema Svarga

(Sumber: Indonesia Trend Forecasting Singularity 2019/2020)

Pendekatan teknik kontemporer melalui subtema Festive Relics dalam bentuk motif dan bentuk tradisional yang tampil ceria, dinamis, dan ilustratif menampilkan kesan keceriaan tradisional dalam interpretasi modern. Subtema ini merupakan sebuah perayaan identitas budaya. 
Serat Rupa Journal of Design, July 2019, Vol.3, No.2: 77-92

E-ISSN: 2477-586X, ISSN: 2338-3348 | https://doi.org/10.28932/srjd.v3i2.1728 | Received: 24-06-2019, Accepted: 25-07-2019 Yovita Sabatini Daeli, Dewi Isma Aryani, Indra Janty

Perancangan Busana Ready To Wear Deluxe dengan Inspirasi The culture of Animal Spirit dari Suku Indian

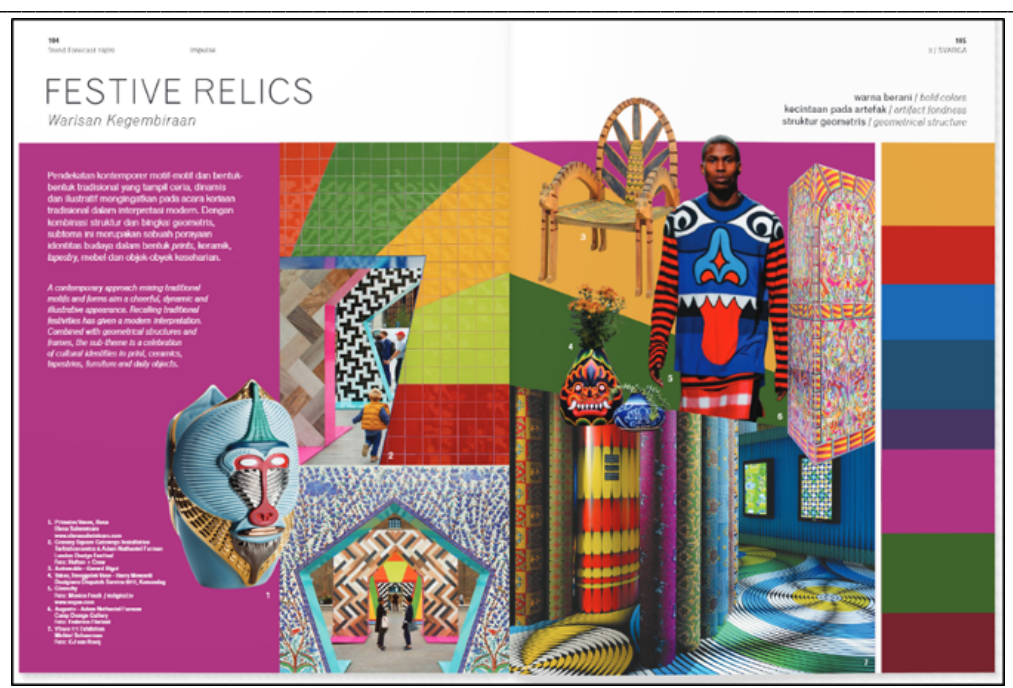

Gambar 9. Subtema Festive Relics

(Sumber: Indonesia Trend Forecasting Singularity 2019/2020)

Berdasarkan pemilihan tema Svarga dan subtema Festive Relics tersebut di atas, maka kaitan dengan penelitian dan perancangan ini sudah sesuai. Penduduk Indian terbagi atas beberapa wilayah yang hidup dalam kelompok suku secara terpisah di benua Amerika. Meskipun demikian banyak dari mereka memiliki kepercayaan dan budaya yang sama. Suku Indian merupakan penduduk asli Amerika Utara yang terkenal dengan tradisi, gaya hidup, bentuk seni, dan kepercayaan yang menjadi suatu tradisi kebudayaan Suku Indian. Salah satunya tradisi kepercayaan terhadap roh hewan yang berkaitan dengan agama Suku Indian yaitu Animisme. Roh hewan dalam Suku Indian sangat dihormati dan dianggap suci, sehingga dalam budaya dan kehidupan sehari-hari mereka selalu dikaitkan dengan roh hewan, seperti: bentuk seni, upacara adat, dan gaya hidup sangat berkaitan dengan roh hewan tersebut (Linda, 2012).

Roh hewan dianggap sebagai makhluk tertinggi yang memiliki kekuatan supernatural yang menjadi pelindung, pembimbing, dan sebagai pemandu jalan untuk menjalani kehidupan di dunia. Sebagai wujud dari roh hewan, Suku Indian menggambarkan ke dalam bentuk seni yaitu seni totem dan simbol-simbol dalam tradisi kebudayaan. Dalam kepercayaan roh hewan ada beberapa hewan yang dianggap penting sebagai tahapan aspek kehidupan Suku Indian yaitu: elang, serigala, beruang, dan bison sebagai lambang dasar struktur kehidupan Suku Indian dengan menggabungkan simbol berdasarkan arah mata angin, musim, elemen, dan warna (Linda, 2012).

Perancangan dalam penelitian ini mengangkat konsep yang terinspirasi dari The Culture of Animal Spirit berupa lambang dan simbol dari keempat hewan yang dianggap penting 
Serat Rupa Journal of Design, July 2019, Vol.3, No.2: 77-92

E-ISSN: 2477-586X, ISSN: 2338-3348 | https://doi.org/10.28932/srjd.v3i2.1728 | Received: 24-06-2019, Accepted: 25-07-2019 Yovita Sabatini Daeli, Dewi Isma Aryani, Indra Janty

Perancangan Busana Ready To Wear Deluxe dengan Inspirasi The culture of Animal Spirit dari Suku Indian

dalam tahapan aspek kehidupan Suku Indian, dengan masing-masing hewan memiliki makna dan tujuan sebagai arah proses tahapan kehidupan mulai dari kelahiran, masa remaja, masa dewasa, hingga kematian. Koleksi yang dibuat berdasarkan data penelitian yang diperoleh adalah busana ready to wear deluxe berjudul OTODEM dengan mengacu pada Indonesia Trend Forecasting 2019-2020 Singularity yakni tema Svarga dan subtema Festive Relics. Svarga berasal dari bahasa Sansekerta berarti surga dan tema tren ini mewakili latar belakang kultural dari simbol dengan dampak yang dihasilkan manusia, menciptakan surga di atas bumi. Konsep desain tema Svarga ini dalam koleksi OTODEM menampilkan nuansa etnik namun tetap modern dari segi bentuk atau potongan busana. Konsep yang diterapkan pada desain koleksi OTODEM mengadaptasi bentuk rupa dari roh hewan yaitu: elang, serigala, beruang, dan bison di setiap busana dengan menerapkan simbol arah mata angin, musim, elemen, dan warna. Koleksi busana OTODEM menampilkan empat tampilan busana ready to wear deluxe yang pada setiap tampilan busananya terdapat manipulating fabric berupa: sablon, macrame, dan stitching. Setiap look busana terdiri dari tiga lapisan potongan dengan tampilan tampak depan dan belakang yang berbeda seperti tampak dalam gambar berikut:

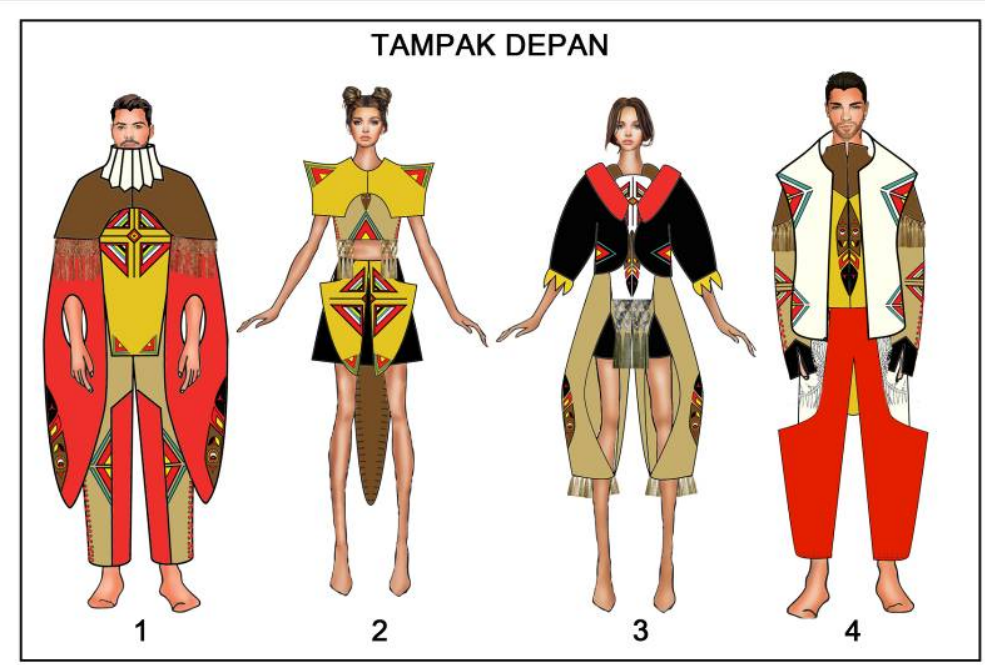

Gambar 10. Desain koleksi OTODEM tampak depan (Sumber: Data Pribadi, 2019) 


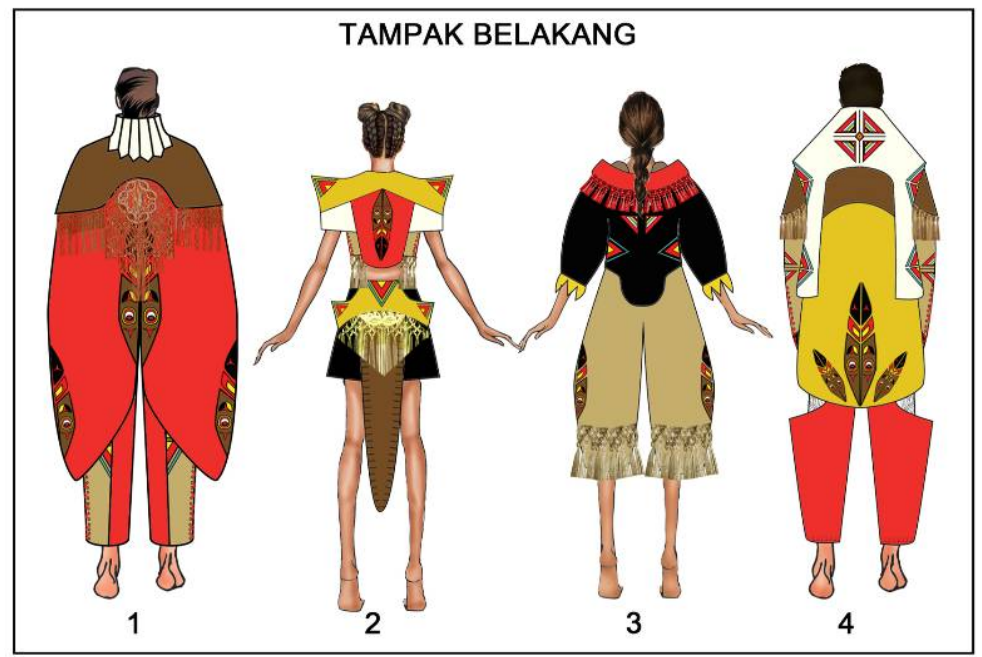

Gambar 11. Desain koleksi OTODEM tampak belakang

(Sumber: Data Pribadi, 2019)

\section{Desain Look 1}

Pada look pertama koleksi OTODEM berupa busana pria dengan tiga potong lapisan yaitu outer, atasan, dan celana. Pada look 1 tersebut menggambarkan kesan dan karakter hewan elang yang merupakan lambang atau simbol dari lingkaran kehidupan pertama yaitu awal kehidupan (kelahiran). Elang dianggap hewan suci oleh Suku Indian, karena sebagai lambang dari matahari dan juga digambarkan sebagai penguasa langit. Elang juga melambangkan kekuatan, keberanian, kepemimpinan, dan prestise yang luar biasa. Dalam aspek kehidupan Suku Indian, elang dianggap sebagai lambang dari spiritual awal kehidupan yang seolah-olah turun dari langit dan menjadi penguasa atas langit. Pada lingkaran kehidupan, simbol warna pendukung untuk awal kehidupan yaitu warna merahoranye sebagai ciri atau simbol matahari, yang juga menjadi simbol dari elang.

Pada bagian outer look 1 menunjukkan kesan gagah seekor elang, bagian leher outer mengikuti pola leher elang, dan bentuk dari outer juga mengikuti bentuk sayap elang dengan menonjolkan bagian dari elang, seperti: dada dan pundak elang pada bagian depan outer dibuat cekung. Sedangkan untuk manipulating yang diterapkan berupa macrame pada tepi tumpukan atas outer bagian depan dan bagian belakang sebagai ciri khas dari Suku Indian. Pada bagian atasan terdapat bentuk trapesium mengerucut ke bawah dengan lengan dan bagian samping atasan dibuka sebagai opening yang diberi manipulating cross stitch, serta pada bagian celana dibuat potongan dan manipulating berupa festoon stitch untuk tetap menampilkan ciri khas Suku Indian. Warna dominan pada look 1 ini adalah warna merah-oranye. Untuk menunjukkan keserasian antara look 1 hingga 
Serat Rupa Journal of Design, July 2019, Vol.3, No.2: 77-92

E-ISSN: 2477-586X, ISSN: 2338-3348 | https://doi.org/10.28932/srjd.v3i2.1728 | Received: 24-06-2019, Accepted: 25-07-2019 Yovita Sabatini Daeli, Dewi Isma Aryani, Indra Janty

Perancangan Busana Ready To Wear Deluxe dengan Inspirasi The culture of Animal Spirit dari Suku Indian

look 4 diletakkan motif tertentu untuk tetap menampilkan kesamaan setiap look. Pada motif yang ada juga menggambarkan arah mata angin dan bulu sebagai ciri khas dari Suku Indian dengan variasi ukuran yang berbeda disesuaikan dengan siluet busana.

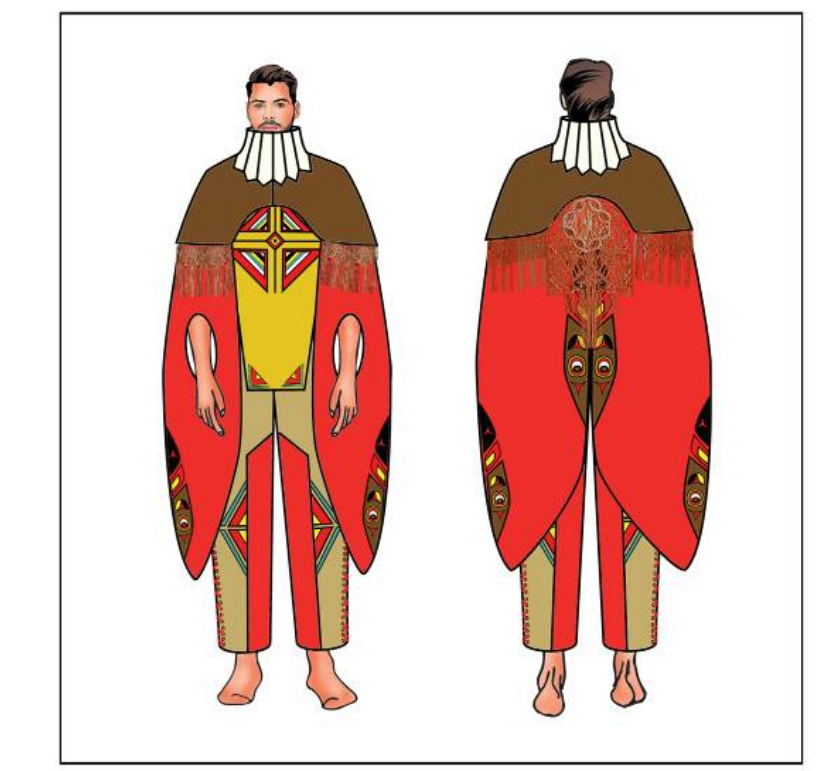

Gambar 12. Desain Look 1 tampak depan dan tampak belakang (Sumber: Data Pribadi, 2019)

\section{Desain Look 2}

Pada look kedua terdapat tiga potong busana yaitu cape, crop tee, dan rok yang ditumpuk untuk menggambarkan kesan dan karakter hewan serigala sebagai lambang atau simbol dari lingkaran kehidupan kedua yakni pertumbuhan (masa remaja). Serigala dianggap hewan suci oleh Suku Indian, lambang dari bulan dan juga sebagai penguasa atas pembaruan. Serigala juga melambangkan kecerdasan, kekuatan, keindahan, dan kepercayaan diri. Sebagai aspek kehidupan Suku Indian, serigala dianggap sebagai lambang dari emosional karena sebagai lambang kedua dari kehidupan yang seolah-olah memasuki fase remaja dalam masa pertumbuhan memiliki sifat emosional, ingin bebas, dan lincah. Pada lingkaran kehidupan simbol warna pendukung untuk pertumbuhan yaitu warna kuning sebagai ciri atau simbol bulan. Merah-oranye sebagai warna matahari yang juga sebagai simbol dari elang.

Pada bagian cape look kedua menunjukkan kesan bebas dengan bentuk mengikuti kepala serigala yang menonjolkan bagian kepala, dada, dan pundak serigala pada bagian depan cape, bagian pundak cape dibuat seperti telinga serigala dan diberi motif sablon pada bagian pundak dan belakang busana untuk mencirikan Suku Indian. Pada bagian atasan atau crop-tee dibuat sederhana dengan bagian samping atasan dibuka dan diberi 
Serat Rupa Journal of Design, July 2019, Vol.3, No.2: 77-92

E-ISSN: 2477-586X, ISSN: 2338-3348 | https://doi.org/10.28932/srjd.v3i2.1728 | Received: 24-06-2019, Accepted: 25-07-2019 Yovita Sabatini Daeli, Dewi Isma Aryani, Indra Janty

Perancangan Busana Ready To Wear Deluxe dengan Inspirasi The culture of Animal Spirit dari Suku Indian

manipulating cross stitch, motif sablon, dan macrame untuk memperkuat kesan ciri khas Suku Indian. Pada bagian rok dibuat potongan berupa tumpukan depan dan belakang, dan bagian belakang diberi kesan seperti ekor serigala dengan manipulating festoon stitch di sekeliling ekor, macrame pada bagian belakang rok untuk kesan ciri khas Suku Indian. Warna yang menjadi dominan untuk look 2 ini adalah warna kuning. Pada bagian motif sablon menerapkan variasi ukuran motif disesuaikan komposisi bagian siluet pada setiap look.

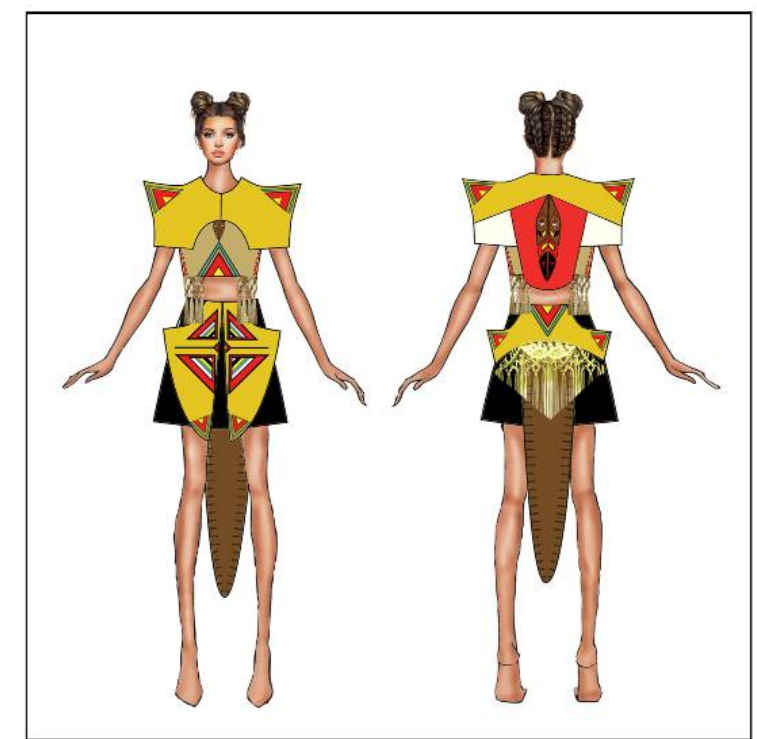

Gambar 13. Desain Look 2 tampak depan dan tampak belakang (Sumber: Data Pribadi, 2019)

\section{Desain Look 3}

Pada look ketiga terdapat 3 potong berupa outer, crop-top, dan celana yang ditumpuk yang menampilkan kesan dan karakter hewan beruang sebagai lambang atau simbol lingkaran kehidupan ketiga yaitu masa dewasa (orang tua). Beruang dianggap hewan pelindung oleh Suku Indian, juga sebagai lambang dari bintang, dan juga digambarkan sebagai penguasa atas perjalanan atau berkelana. Beruang juga melambangkan siklus hidup kematian, contoh panutan, dan kekuatan. Sebagai salah satu aspek kehidupan Suku Indian, beruang dianggap sebagai lambang dari intelektual karena menjadi lambang ketiga dari kehidupan yang seolah-olah memasuki fase dewasa dan semakin tua karena telah melewati perjalanan hidup dengan banyak pengalaman semasa hidup supay menjadi pelajaran bagi kaum muda. Pada lingkaran kehidupan simbol warna pendukung untuk kedewasaan yaitu warna hitam sebagai ciri atau simbol bintang di langit gelap, simbol pelindung dalam kepercayaan Suku Indian yakni bintang sebagai petunjuk jalan bagi mereka yang tersesat atau terpisah dari rombongan. 
Serat Rupa Journal of Design, July 2019, Vol.3, No.2: 77-92

E-ISSN: 2477-586X, ISSN: 2338-3348 | https://doi.org/10.28932/srjd.v3i2.1728 | Received: 24-06-2019, Accepted: 25-07-2019 Yovita Sabatini Daeli, Dewi Isma Aryani, Indra Janty

Perancangan Busana Ready To Wear Deluxe dengan Inspirasi The culture of Animal Spirit dari Suku Indian

Pada bagian outer busana ketiga menunjukkan kesan melindungi, bentuk outer mengikuti bentuk tubuh beruang dengan menonjolkan bagian seperti: lengan, telinga, dan kaki beruang pada bagian lengan outer yang dibuat siluet bulky dengan diberi motif sablon dan diberi manipulating macrame untuk menampilkan ciri khas Suku Indian. Pada bagian atasan atau crop-top pundak dibuat seperti telinga beruang, dibuat sederhana pada bagian depan diberi manipulating cross-stitch, motif sablon, dan macrame untuk memperkuat kesan ciri khas Suku Indian. Pada bagian celana dibuat potongan berupa hotpants dan ditumpuk lagi bagian luar celana sehingga berbentuk bulky, bagian depan dibuat lubang agar bagian hotpants dapat terlihat, bagian depan dan belakang diberi manipulating motif bulu yang disablon, dan macrame pada bagian belakang celana untuk memberikan kesan ciri khas Suku Indian. Warna dominan untuk look tiga ini adalah warna hitam. Pada bagian motif sablon menampilkan variasi ukuran motif yang disesuaikan komposisinya dengan bagian siluet pada setiap look.

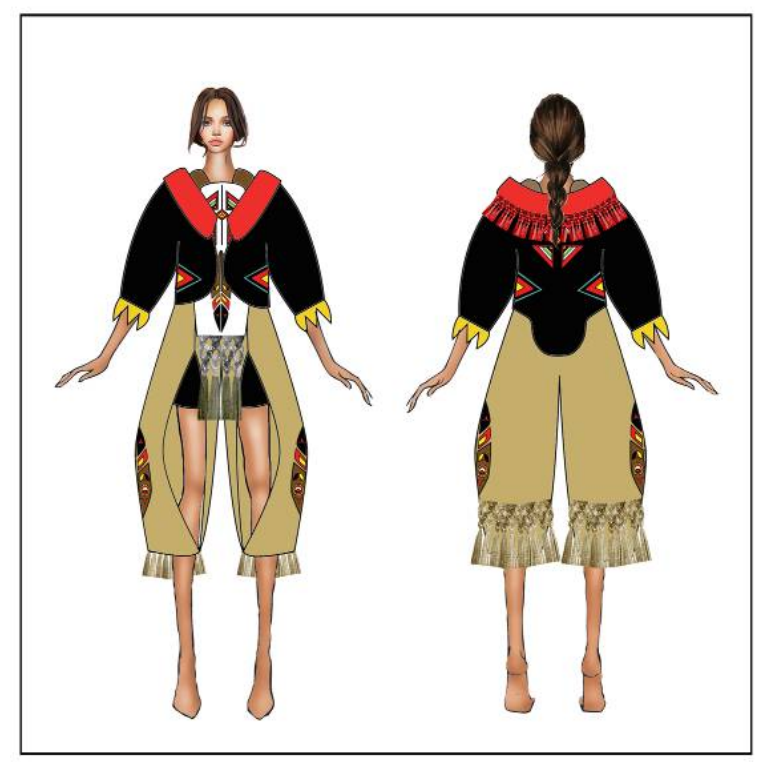

Gambar 14. Desain Look 3 tampak depan dan tampak belakang (Sumber: Data Pribadi, 2019)

\section{Desain Look 4}

Pada look keempat terdapat tiga potong busana berupa: outer, kemeja, dan celana yang ditumpuk menggambarkan kesan dan karakter bison atau buffalo yang menjadi lambang atau simbol lingkaran kehidupan terakhir yaitu kematian (kembali pada bumi). Bison dianggap hewan suci dan pelindung oleh Suku Indian, lambang bumi, dan juga digambarkan sebagai leluhur. Bison juga melambangkan siklus fase terakhir kehidupan yaitu kematian, lambang akar dari leluhur, penyampai pesan sebagai pengingat kepada 
Serat Rupa Journal of Design, July 2019, Vol.3, No.2: 77-92

E-ISSN: 2477-586X, ISSN: 2338-3348 | https://doi.org/10.28932/srjd.v3i2.1728 | Received: 24-06-2019, Accepted: 25-07-2019 Yovita Sabatini Daeli, Dewi Isma Aryani, Indra Janty

Perancangan Busana Ready To Wear Deluxe dengan Inspirasi The culture of Animal Spirit dari Suku Indian

leluhur yang telah mendahului. Sebagai salah satu aspek kehidupan Suku Indian, bison dianggap sebagai lambang terakhir dari kehidupan yang seolah-olah memasuki fase kematian dengan tubuh yang kembali pada bumi dan roh kembali ke atas. Pada lingkaran kehidupan, simbol warna pendukung untuk fase terakhir yaitu warna putih sebagai ciri atau simbol roh dan bumi.

Pada bagian outer look keempat menampilkan kesan besar dan gagah dari bentuk outer mengikuti bentuk tubuh bison dengan menonjolkan bagian seperti pundak pada outer bersiluet bulky, bagian atas diberi motif sablon pada lubang lengan dan bawah outer depan serta belakang. Pada bagian kemeja tepatnya yoke dan lengan kemeja dibuat seperti telinga bison, ditambahkan manipulating cross stitch, motif sablon, dan macrame untuk memperkuat kesan ciri khas Suku Indian. Pada bagian bawahan dibuat potongan berupa tumpukan celana dan ditumpuk bentuk bulky seperti kaki bison, bagian depan celana dan belakang diberi manipulating macrame sebagai kesan ciri khas Suku Indian. Warna dominan untuk look keempat ini adalah warna putih ditambahkan variasi ukuran motif yang disesuaikan komposisi siluet busana.

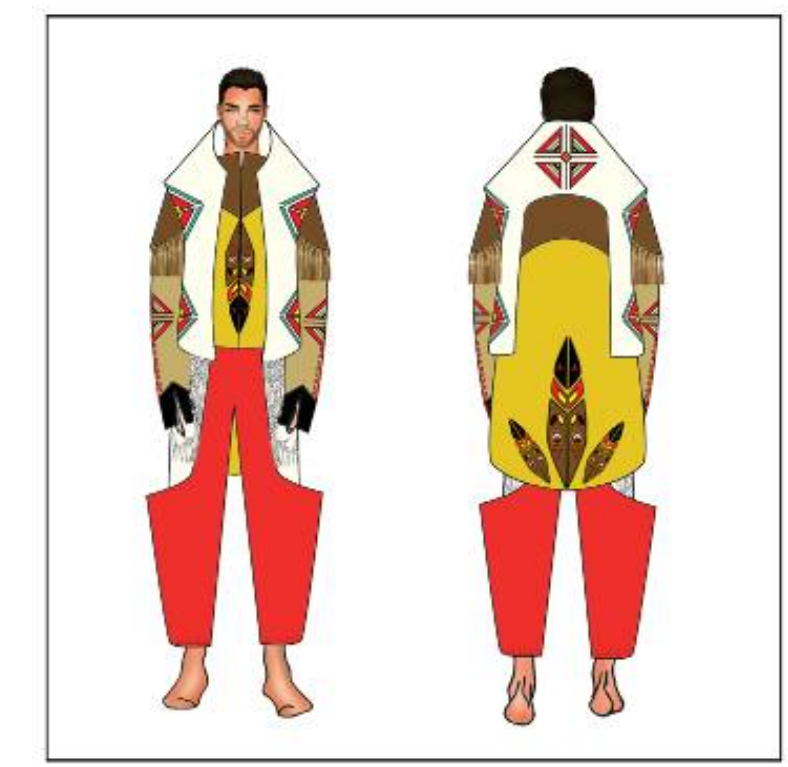

Gambar 15. Desain Look 4 tampak depan dan tampak belakang (Sumber: Data Pribadi, 2019)

\section{PENUTUP}

Koleksi busana ready-to-wear deluxe OTODEM menerapkan simbol dan lambang arah mata angin, elemen warna, dan bentuk rupa dari hewan yang dianggap suci dan dihormati oleh Suku Indian. Perwujudan busana tersebut tampak dalam manipulasi sablon polyflex, sablon flocking, macrame, dan stitching. Referensi sekaligus batasan desain dari koleksi ini 
Serat Rupa Journal of Design, July 2019, Vol.3, No.2: 77-92

E-ISSN: 2477-586X, ISSN: 2338-3348 | https://doi.org/10.28932/srjd.v3i2.1728 | Received: 24-06-2019, Accepted: 25-07-2019 Yovita Sabatini Daeli, Dewi Isma Aryani, Indra Janty

Perancangan Busana Ready To Wear Deluxe dengan Inspirasi The culture of Animal Spirit dari Suku Indian

berdasarkan tema Svarga dan subtema Festive Relics yang dipaparkan dalam buku Indonesia Trend Forecasting 2018-2019 Singularity dengan banyak menampilkn stilasi motif tertentu yang diadaptasi dari simbol kepercayaan Suku Indian dan juga penggunaan warna-warna cerah serta berani dalam setiap busananya. Perancangan busana OTODEM menampilkan nuansa etnik namun tetap modern dari segi bentuk atau potongan busana. Kendala penerapan teknik sablon, macrame, stitching dalam koleksi ini merupakan hal yang sangat perlu mendapatkan perhatian dari segi teknis, material yang digunakan, dan juga perhitungan waktu pembuatan dengan segala kemungkinan risiko gagal yang mungkin terjadi.

\section{DAFTAR PUSTAKA}

Alchin, Linda. (2012). History of Native Americans. USA: Siteseen Limited.

Amet El Maat, Tchiya.(2014). Medicine-Wheel, (online), Diunduh 23 Febuari 2019 dar https://www.tchiya.com/2014/09/27/Medicine Wheel Page at tchiya.com.

Bekraf Indonesia Trend Forecasting.(2019). Indonesia Trend Forecasting Singularity 20192020. Jakarta: BD+A Design.

Sponderosa, Uroboro.(2011). Navigating the stars the sun and moon, (online), Diunduh 25 Maret 2019 dari https://ouroborosponderosa.com/2011/12/02/navigating-by-thestars-ii-the-sun-and-moon/

Tim Seni Budayaku.(2017). Macam-macam Tusuk Hias dan Reka Bahan, (online), Diunduh 15 Febuari 2019 dari https://www.senibudayaku.com/2017/12/macam-macam-tusukhias-dan-penjelasannya.html 